a Fundação Oswaldo Cruz, Farmanguinhos, Programa de Pós-Graduação em Pesquisa Translacional em Fármacos e Medicamentos, Rua Sizenando Nabuco 100, Manguinhos, CEP 21021-250, Rio de Janeiro-RJ, Brazil.

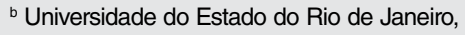
Instituto de Biologia, Programa de Pósgraduação em Biologia Vegetal, Maracanã, CEP 20550-013, Rio de Janeiro-RJ, Brazil.

c Instituto de Pesquisas Jardim Botânico do Rio de Janeiro, Rua Pacheco Leão 915, Jardim Botânico, CEP 22460-030, Rio de Janeiro-RJ, Brazil;

d Universidade Federal do Rio de Janeiro, Campus Macaé, Laboratório de Produtos Bioativos, Av. Aluizio da Silva Gomes 50, Novo Cavaleiros, CEP 27930-560, MacaéRJ, Brazil;

e Universidade Estadual do Norte Fluminense Darcy Ribeiro, Centro de Biociências e Biotecnologia, Laboratório de Biologia do Reconhecer, Av. Alberto Lamego 2000, Parque Califórnia, CEP 28013-602, Campos dos Goytacazes-RJ, Brazil;

' Universidade Castelo Branco, Faculdade de Farmácia, Av. de Santa Cruz 1631, Realengo, CEP 21710-255, Rio de Janeiro-RJ, Brazil.

*E-mail: davysonmoreira@ hotmail.com

Recebido: 22 de Março de 2021

Aceito: 22 de Março de 2021

Publicado online: 6 de Outubro de 2021

\section{Antimycobacterial Activity and Chemical Characterization of the Essential Oils from Reproductive Organs of Piper Ihotzkyanum Kunth (Piperaceae)}

\author{
Atividade Antimicobacteriana e Caracterização Química dos Óleos Essenciais \\ dos Órgãos Reprodutivos de Piper Ihotzkyanum Kunth (Piperaceae)
}

Claudete Costa-Oliveira, ${ }^{a}$ Ygor J. Ramos, ${ }^{a, b, c}$ George A. Queiroz, ${ }^{c}$ Elsie F. Guimarães, ${ }^{c}$ Marlon Heggdorne-Araujo, ${ }^{d}$ Elena B. Lassounskaia, ${ }^{e}$ Michelle F. Muzitano, ${ }^{d}$ Diego S. Marcelino, ${ }^{\dagger}$ Davyson de L. Moreira ${ }^{a, b, *(\mathbb{B})}$

Piper lhotzkyanum Kunth belongs to the Piperaceae family, is a medicinal plant also known as "Aperta-ruão" and "Beque-cheiroso". This species is used in folk medicine to treat rheumatism, sore throats, gastrointestinal problems, and bronchial conditions. The present study aimed to analyze the chemical composition and biological activity of the essential oils (EOs) from reproductive organs of $P$. lhotzkyanum against strains of Mycobacterium tuberculosis H37Rv (ATCC, 25618). The EOs were obtained by hydrodistillation and characterized by GC-MS and GC-FID. Chemical composition of the volatile mixture showed to be rich in monoterpenes for both inflorescences (IFl) and infructescences (IFr). These monoterpenes included $\alpha$-phellandrene, $\beta$-phellandrene, $\alpha$-pinene, and $\beta$-pinene for both samples. The antimycobacterial activity showed minimum inhibitory concentration (MIC) of $76.51 \mu \mathrm{g} / \mathrm{mL}$ and $128 \mu \mathrm{g} / \mathrm{mL}$ for IFr and IFl, respectively. By these results, the volatile fraction of IFr showed promising activity against $M$. tuberculosis. The chemical composition and antimicrobial properties of IFl and IFr EOs have been reported for the first time.

Keywords: Inflorescence; infructescence; Mycobacterium tuberculosis; monoterpenes, phellandrene.

\section{Introduction}

Piper genus (Piperaceae) has commercial, ecological, and medicinal importance. ${ }^{1}$ Biological properties of essential oils (EOs) from plants of this genus have been reported. ${ }^{2-8}$ The most popular species is $P$. nigrum L., known as black pepper, widely used as a condiment and as medicine, mainly in Asia. ${ }^{9}$

Piper lhotzkyanum Kunt is a perennial shrub from 1 to $2 \mathrm{~m}$ high and popularly known as "beque-cheiroso", ${ }^{10-11}$ common in the Brazilian Amazon rainforest and the Brazilian Atlantic forest. ${ }^{12}$ This species is used in folk medicine in infusion preparation for the treatment of rheumatism, sore throats, gastrointestinal problems, bronchial conditions, among others. The infructescences of $P$. lhotzkyanum have a strong flavor and produce a burning sensation and analgesia when chewed..$^{10,13-14}$

Tuberculosis (TB) is a neglected disease caused by Mycobacterium tuberculosis and is one of the most significant motive of death since $19^{\text {th }}$ century. ${ }^{8}$ According to WHO 230,000 children died from one million infected with TB. ${ }^{15}$ In this scenario, it is worth noting the increase in multidrug-resistant TB to drugs such as fluoroquinolones and injectables such as amikacin, kanamycin, capreomycin, further reducing the range of treatment options. There is an urgency regarding the discovery of new drugs and an alternative would be the combination of commercial drugs with natural compounds that could be tested to enhancer antibiotic activity. ${ }^{15-19}$ It is reported that natural products, including EOs, and their isolated compounds have inhibitory activity against the growth of $M$. tuberculosis, while some have been selected as prototype molecules for the development of new anti-tuberculosis agents. ${ }^{20-22}$

Despite being well reported that EOs of the Piper genus have demonstrated biological activities, ${ }^{2-8}$ such as antibacterial, antiproliferative, ${ }^{23-26}$ antileishmanial, ${ }^{16}$ insecticidal, fungicidal, ${ }^{25}$ antioxidant, and cytotoxic, ${ }^{26}$ to date there is nothing published demonstrating the EO composition of $P$. lhotzkyanum with biological properties, besides a study showing great ovicidal activity against Anticarsia gemmatalis (soybean caterpillar) $\left(\mathrm{LC}_{50}=1.6 \%\right) .{ }^{27}$ 
Also, the chemical composition of EOs from inflorescences (IFl) and infructescences (IFr) (reproductive organs) for $P$. lhotzkyanum has never been described. Therefore, the aim of this study was to perform an analysis of the EO chemical composition of reproductive organs of $P$. lhotzkyanum from altitude in addition to reporting its antimycobacterial activity.

\section{Material and Methods}

\subsection{Plant material and essential oil extraction}

Inflorescences and infructescences of Piper lhotzkyanum Kunth were collected in a region of altitude in the Atlantic Forest at Serra dos Órgãos National Park, near the city of Teresópolis, Rio de Janeiro (Altitude: $1,144.69 \mathrm{~m}$ and GPS: $12^{\circ} 11^{\prime} 45^{\prime} \mathrm{S} ; 38^{\circ} 58^{\prime \prime} 05^{\prime} \mathrm{W}$ ) in 2019 . This study was registered in the Genetic Heritage Management Council (CGEN n. AE4E953) and in the Biodiversity Authorization and Information System (SISBIO n. 57296-1). The botanical identification was made by Dr. Elsie Franklin Guimarães and Msc. George Azevedo Queiroz at Rio de Janeiro Botanical Garden Research Institute (JBRJ). Herborized samples were deposited at the Herbarium RB (01426181). The fresh plant material $(100 \mathrm{~g}, 700 \mathrm{~mL}$ of distilled water) was subjected to hydrodistillation for $2 \mathrm{~h}$ in a Clevenger-type apparatus for EOs extracting. The obtained samples were drying over anhydrous sodium sulfate $\left(\mathrm{Na}_{2} \mathrm{SO}_{4}\right.$, Sigma-Aldrich, Brazil), kept in sealed amber vials, and stored at $-20{ }^{\circ} \mathrm{C}$ for five days until gas chromatography (GC) analysis. The total yield of EO was registered as a percentage value, considering weight of $\mathrm{EO}(\mathrm{g}) / 100 \mathrm{~g}$ of fresh plant material. ${ }^{28-30}$

\subsection{Essential oils analysis}

The obtained EOs were diluted in dichloromethane (HPLC grade, Tedia, Brazil) until $1.000 \mathrm{ppm}$. All samples were injected $1 \mu \mathrm{L}$, splitless, ${ }^{28-29}$ for chemical identification by gas chromatography coupled to mass spectrometry (GC-MS) and for quantification by $\mathrm{GC}$ coupled to Flame Ionization Detection (GC-FID).

GC-MS analysis was performed using a gas chromatograph 6890 GC coupled to an Agilent MS 5973N mass spectrometer (Hewlett-Packard, Brazil), operating at $70 \mathrm{eV}$ of ionization energy, in positive mode, and mass range of $\mathrm{m} / \mathrm{z} 40-600$ atomic mass units (u). The GC conditions were an HP-5MS capillary column ( $30 \mathrm{~m}$ x $0.25 \mathrm{~mm}$ id $\mathrm{x}$ $0.25 \mu \mathrm{m}$ film thickness), temperature programming from $60{ }^{\circ} \mathrm{C}$ to $240{ }^{\circ} \mathrm{C}$ with an increase of $3^{\circ} \mathrm{C} / \mathrm{min}$, using helium (99.99\%) as carrier gas at a constant flow rate of $1.0 \mathrm{~mL} / \mathrm{min}$. The injector and detector were set at $270{ }^{\circ} \mathrm{C}$, the transfer line was set at $280^{\circ} \mathrm{C}$ and samples were injected $1 \mu \mathrm{L}$ splitless.

GC-FID analysis was achieved in an HP-Agilent 6890 gas chromatograph (Hewlett-Packard, Brazil) equipped with an HP-5MS capillary column ( $30 \mathrm{~m} \times 0.25 \mathrm{~mm}$ id $\times 0.25 \mu \mathrm{m}$ film thickness), temperature setting from $60{ }^{\circ} \mathrm{C}$ to $240{ }^{\circ} \mathrm{C}$, with an increase of $3{ }^{\circ} \mathrm{C} / \mathrm{min}$, using hydrogen as carrier gas at a constant flow rate of $1.0 \mathrm{~mL} / \mathrm{min}$. The injector and detector temperatures were set at $270{ }^{\circ} \mathrm{C}$. Samples were injected $1 \mu \mathrm{L}$ splitless. Retention indices (RI) as well as the quantification of the peak area were achieved based on the results of the GC-FID. Relative percentage of individual components was calculated based on the peak areas of the GC without correction of the FID response factor. The compounds were identified based on the fragmentation pattern of the mass spectrum compared with literature records (National Institute of Standards and Technology - NIST, 2010; Wiley7n), as well as calculated RI referring to a homologous series of $n$-alkanes $\left(\mathrm{C}_{8}-\mathrm{C}_{28}\right.$, Sigma -Aldrich, Brazil). ${ }^{31-32}$

\subsection{Antibacterial activity}

The standard virulent strain of Mycobacterium tuberculosis $\mathrm{H} 37 \mathrm{Rv}$ (ATCC, 25618) was grown in 7H9 (BACTO) culture medium, supplemented with $10 \%$ albumin, dextrose, catalase (ADC) $\left(\mathrm{BC}^{\circledR}\right), 0.05 \%$ of tween 80 , and kept in an incubator (Scientific - Water-Jacketed incubator) at $37{ }^{\circ} \mathrm{C}$ and $5 \% \mathrm{CO}_{2}$, until the beginning of the growth phase. Samples were evaluated for their antimycobacterial activity using the tetrazole salt assay in a 96-well microplate at concentrations of $16,32,64$ and $128 \mu \mathrm{g} / \mathrm{mL}$. For this test, a suspension was prepared with M. tuberculosis $\mathrm{H} 37 \mathrm{Rv}$ ( $300 \mu \mathrm{L}$ of mycobacteria in 7.2 of $7 \mathrm{H} 9$ culture medium supplemented with $10 \% \mathrm{ADC}$, approximately $3 \times 10^{7}$ Colony Forming Units - CFU/ $\mathrm{mL}$ ) and kept in an incubator at $37{ }^{\circ} \mathrm{C}$ and $5 \% \mathrm{CO}_{2}$ until the beginning of the log phase (exponential growth phase). The CFU dosage for turbidity was standardized and monitored in a spectrophotometer (Hitachi - Model U-1100) at an optical density (O.D.) of 600 $\mathrm{nm}$. Subsequently, in the logarithmic growth phase, $50 \mu \mathrm{L}$ of this suspension were plated in a 96-well microplate $\left(1 \times 10^{6}\right.$

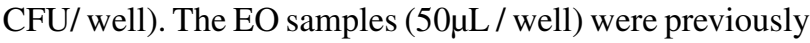
diluted in $7 \mathrm{H} 9$ supplemented with $\mathrm{ADC}$ in a concentration 2 times higher than the desired final concentration and added to the microplate where the mycobacteria already contained. The sealed plate was incubated at $37{ }^{\circ} \mathrm{C}$ and $5 \% \mathrm{CO}_{2}$ for 5 days. After this period, $10 \mu \mathrm{L}$ per well of a $5 \mathrm{mg} / \mathrm{mL}$ solution of tetrazole 3-[4,5-dimethylthiazol2-yl]-2,5-diphenyl-tetrazole (MTT) in saline phosphate buffer (PBS) was added sterile. Three hours later, $100 \mu \mathrm{L}$ of the lysis buffer was added ( $20 \% \mathrm{w} / \mathrm{v}$ sodium dodecyl sulfate (SDS)/ 50\% dimethylformamide (DMF) in distilled water $-\mathrm{pH} 4.7)$. The microplate reading was performed on a spectrophotometer at $570 \mathrm{~nm}$ (Hitachi - Model U-1100). ${ }^{33}$ Treatment with rifampicin $(0.032 ; 0.08 ; 0.2$ and $1 \mu \mathrm{g} / \mathrm{mL})$ was used as a positive control of antimycobacterial activity in the wells containing only the bacilli. Negative control was set in wells containing bacilli and without treatment. To calculate the percentage of inhibition of mycobacterial growth, equation (1) was used. 


$$
100-\left(O . D \cdot \text { sample }-O . D \cdot \cdot_{C+}\right) \times\left(O . D \cdot C^{-O}-D_{C+}\right.
$$

\subsection{Statistical analysis}

The statistical analysis to show differences in the antimicrobial activity of the analyzed EOs was performed by the ANOVA test, using Statistica ${ }^{\circledR}$ software. The value of $p<0.05$ was considered statistically significant.

\section{Results}

Strongly yellowish essential oils were obtained from fresh IFr and IFl of P. lhotzkyanum. The yield of EOs was at 2.4\% for IFl and $2.5 \%$ for IFr (w/w). It was possible to identify a total of 39 and 20 compounds that correspond to $93.9 \%$ and
$97.1 \%$ of total chemical composition, respectively, which are shown in Table 1. A total of 29 compounds for IFl and 12 for IFr was identified in less than $1.0 \%$ of relative percentage, and corresponding to $11.3 \%$ and $3.2 \%$, respectively.

The relative percentage of monoterpenes in the EOs of the reproductive organs was quite pronounced (IFl - 86.16\%; IFr - 92.34\%). The major constituents were identified as non-oxygenated monoterpenes $\alpha$-phellandrene (IFr - 56.4\%; IFl - 48.52\%), $\beta$-phellandrene (IFr - 14.5\%; IFl-8.49\%), $\alpha$-pinene (IFr $-6.8 \%$; IFl - 11.25) and $\beta$-pinene (IFr-6.9\%; IFl-8.35) (Figure 1). The mass spectra of the main components from the reproductive organs of $P$. lhotzkyanum (70 eV, positive mode, $m / z 40-600 \mathrm{u}$ ) is shown on the supplementary material (Figures S1-4).

The antimicrobial activity of the EOs is shown in Figure 2. The sample IFr showed greater activity than IFl (MIC of 76 and $128 \mu \mathrm{g} / \mathrm{mL}$, respectively).<smiles>CC1=CCC2CC1C2(C)C</smiles>

$\alpha$-pinene<smiles>C=C1CCC2CC1C2(C)C</smiles>

$\beta$-pinene $\beta$-phellandrene<smiles>C=C1C=CC(C)CC1</smiles>

ellandrene

Figure 1. Chemical structures of the main identified constituents in the essential oils from inflorescences and infructescences of Piper lhotzkyanum Kunth

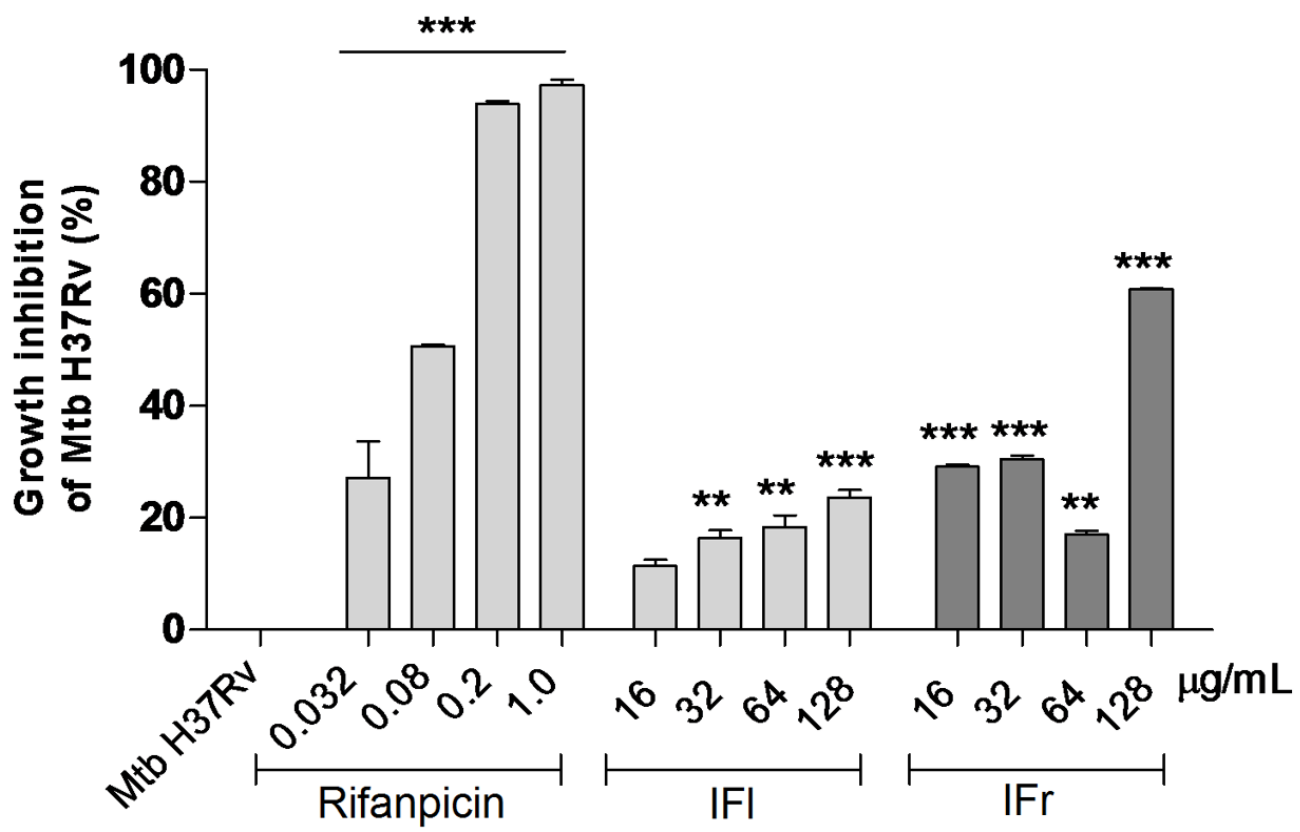

Figure 2. Growth inhibition of Mycobacterium tuberculosis H37Rv after treatment with Piper lhotzkyanum Kunth essential oils Legend. Results of MTT assay after 5 days of incubation in the presence of samples at concentrations of $16,32,64$ and $128 \mu \mathrm{g} / \mathrm{mL}$. Positive control $=M$. tuberculosis $\mathrm{H} 37 \mathrm{Rv}$ treated with rifampicin (reference drug); negative control $=M$. tuberculosis H37Rv without treatment. Statistical analysis: Oneway ANOVA followed by the Tukey test $* * * p<0.001$, ** $p<0.01$ and $* p<0.05$ compared to the negative control (Mtb H37Rv $1 \mathrm{x} 10^{6} \mathrm{CFU} / \mathrm{mL}$ ). Triplicate results represented as mean \pm standard error. IFl - Essential oil from inflorescences; IFr - Essential oil from infructescences. 
Table 1. Chemical composition of the essential oil from reproductive organs of Piper lhotzkyanum Kunth.

\begin{tabular}{|c|c|c|c|c|}
\hline \multirow{2}{*}{ Compounds $^{\mathrm{a}}$} & \multirow{2}{*}{ RI cal ${ }^{\mathbf{b}}$} & \multirow{2}{*}{ RI lit ${ }^{\mathrm{c}}$} & \multicolumn{2}{|c|}{ Relative percentage $(\%)$} \\
\hline & & & IFI & IFr \\
\hline$\alpha$-thujene & 923 & 924 & 0.1 & $\operatorname{tr}$ \\
\hline$\alpha$-pinene & 931 & 932 & 11.2 & 6.8 \\
\hline camphene & 944 & 946 & 0.3 & - \\
\hline$\beta$-pinene & 970 & 974 & 8.3 & 6.9 \\
\hline 6-methyl-5-hepten-2-one & 988 & 989 & $\operatorname{tr}$ & $\operatorname{tr}$ \\
\hline myrcene & 995 & 988 & 1.1 & 0.7 \\
\hline$\alpha$-phellandrene & 1009 & 1002 & 48.5 & 56.4 \\
\hline$\delta$-3-carene & 1010 & 1008 & 3.5 & 3.7 \\
\hline$\alpha$-terpinene & 1012 & 1014 & 1.3 & - \\
\hline$p$-cymene & 1022 & 1020 & $\operatorname{tr}$ & $\operatorname{tr}$ \\
\hline$o$-cymene & 1023 & 1022 & - & $\operatorname{tr}$ \\
\hline limonene & 1025 & 1024 & $\operatorname{tr}$ & 1.9 \\
\hline$\beta$-phellandrene & 1028 & 1025 & 8.5 & 14.5 \\
\hline cis- $\beta$-ocimene & 1036 & 1032 & 2.6 & 0.6 \\
\hline$\gamma$-terpinene & 1057 & 1054 & 0.2 & 0.3 \\
\hline terpinolene & 1085 & 1086 & 0.4 & 0.5 \\
\hline linalool & 1103 & 1095 & 1.7 & - \\
\hline unidentified (monoterpene) & - & - & - & 1.8 \\
\hline trans-sabinene hydrate & 1104 & 1098 & $\operatorname{tr}$ & - \\
\hline menth-2-en-1-ol & 1116 & 1118 & $\operatorname{tr}$ & - \\
\hline terpinen 4-ol & 1178 & 1174 & $\operatorname{tr}$ & - \\
\hline$\alpha$-terpineol & 1189 & 1186 & 0.2 & - \\
\hline cis-piperitol & 1205 & 1195 & $\operatorname{tr}$ & - \\
\hline$\alpha$-copaene & 1381 & 1374 & 0.2 & - \\
\hline$\beta$-elemene & 1407 & 1389 & 0.0 & - \\
\hline$\alpha$-gurjunene & 1411 & 1409 & 0.1 & - \\
\hline cis-caryophyllene & 1425 & 1417 & 2.4 & 2.0 \\
\hline$\gamma$-elemene & 1433 & 1434 & 0.5 & - \\
\hline aromadendrene & 1440 & 1439 & 0.1 & - \\
\hline$\alpha$-humulene & 1456 & 1452 & 0.3 & - \\
\hline$\beta$-selinene & 1480 & 1489 & 0.5 & 0.5 \\
\hline$\alpha$-selinene & 1494 & 1498 & 0.6 & 0.1 \\
\hline$\beta$-curcumene & 1496 & 1514 & - & 0.3 \\
\hline$\gamma$-cadinene & 1509 & 1513 & 0.1 & - \\
\hline$\delta$-cadinene & 1518 & 1522 & 0.5 & 0.1 \\
\hline zonarene & 1524 & 1528 & 0.1 & - \\
\hline selina-3,7(11)-diene & 1547 & 1545 & $\operatorname{tr}$ & - \\
\hline germacrene B & 1553 & 1559 & 0.1 & - \\
\hline caryophyllene oxide & 1581 & 1582 & $\operatorname{tr}$ & - \\
\hline guaiol & 1596 & 1600 & $\operatorname{tr}$ & - \\
\hline$\alpha$-epi-muurolol & 1645 & 1640 & 0.1 & - \\
\hline \multicolumn{3}{|c|}{ Non-Oxygenated Monoterpenes } & 86.16 & 92.34 \\
\hline \multicolumn{3}{|c|}{ Oxygenated Monoterpenes } & 1.99 & 1.77 \\
\hline \multicolumn{3}{|c|}{ Non-Oxygenated Sesquiterpenes } & 5.50 & 3.03 \\
\hline \multicolumn{3}{|c|}{ Oxygenated Sesquiterpenes } & 0.18 & 0.00 \\
\hline \multicolumn{3}{|c|}{ Total } & 93.85 & 98.91 \\
\hline
\end{tabular}

${ }^{\mathrm{a}}$ All compounds were identified by MS and RI in accordance with experimental. ${ }^{\mathrm{a}}$ Compounds are listed in order of elution. ${ }^{\mathrm{b}}$ Retention indices calculated from retention times in relation to those of the $n$-alkanes series on a HP-5MS analytical column (see experimental). ${ }^{\circ}$ Retention indices from the literature. $\mathrm{IFl}=$ Inflorescences, $\mathrm{IFr}=$ Infructescences. $\operatorname{tr}=$ compound $<0.05 \%$. 


\section{Discussion}

In this article we analyzed for the first time the chemical composition and the antimycobacterial potential of reproductive organs of the species $P$. lhotzkyanum. This work represents the first biological activity described for the inflorescences and infructescences of this species. Studies referring to the leaf EO of $P$. lhotzkyanum was published before by Krinski (2018), ${ }^{27}$ and showed ovicidal activity.

The EO yields for the reproductive organs $(\sim 2.5 \%, \mathrm{w} / \mathrm{w})$ were considered high, a fact that is not common for species of Piper, with some exceptions, for example, Piper cubeba L. $(4.4 \%, \mathrm{w} / \mathrm{w})$. However more studies is necessary to evaluate this yield during different phenological periods. ${ }^{34-39}$ This fact is crucial in natural products, mainly, to be exploited commercially or in the production of pharmacological assets. Besides, this high EO yield may have an importance role in the ecological issues related to P. lhotzkyanum, such as pollinators attraction or herbivore repellency. Considering herbivore repellency, the identified compounds in the volatile mixture may present important biological properties such as antimicrobial.

This study reported a predominance of non-oxygenated monoterpenes in the reproductive organs which differs from some results found in the literature for other Piper species, ${ }^{39-40}$. The high relative percentage of $\alpha$ - and $\beta$-phellandrenes, that are used in the food and perfume industries are very interesting. ${ }^{41-42}$ Compound $\alpha$-phellandrene, a cyclic monoterpene, is also found in the EOs from plants such as Schinus terebinthifolius Raddi (15.7\%), Solanum erianthum D.Don (17.5\%), Thymus kotschyanus Boiss and Hohen (10.8\%), Cupressus atlantica Gaussen (5.5\%), Anethum graveolens L. (32.0\%), Myrica gale L. (8.0\%) and Piper mullesua D. Don (22.8\%). Literature records showed antinociceptive, anti-inflammatory, ${ }^{43}$ antimicrobial, ${ }^{44}$ anticancer, ${ }^{45}$ and hyperalgesic activities ${ }^{46}$ related to this monoterpene.

The evaluation of antimycobacterial activity for both EOs against strains of $M$. tuberculosis showed promising activity for IFl and IFr. MIC values $<100 \mu \mathrm{g} / \mathrm{mL}$ have been found to be ideal candidates against $M$. tuberculosis, while values of $100-200 \mu \mathrm{g} / \mathrm{mL}$ are considered moderate candidates. ${ }^{8,47}$ Therefore, EO from IFr (MIC $=76 \mathrm{mg} / \mathrm{mL}$ ) could be a promising candidate to proceed in a further study since synergism of EOs with standard drugs used to treat TB may be an option in the treatment of this condition. ${ }^{17}$ Some studies relate the antimicrobial activity of EOs, mainly, to their monoterpenoid constituents. Mechanism of action proposed that monoterpenes act on the disruption and dysregulation of the bacterial membrane function. ${ }^{48-51}$ Interestingly to note that the richest EO in monoterpenes from infructescences showed greater activity, strengthening the hypothesis that they may interact with the phospholipid membranes of M. tuberculosis.

\section{Conclusions}

The chemical composition of the essential oil from reproductive organs of Piper lhotzkyanum is described here for the first time. The studied essential oils and their volatile components can provide an important source of new antimycobacterial agents. In addition, the high essential oils' yield and the great relative percentage of phellandrene may represent an important source of this monoterpene for the industry. The essential oil from infructescences was the most active against $M$. tuberculosis. These findings contribute with new data on the chemical constitution and antimycobacterial potential of the essential oils from reproductive organs of $P$. lhotzkyanum collected at high altitude site in the Atlantic Forest.

\section{Acknowledgment}

This work was supported by CAPES, FAPERJ and PROEP-CNPq (407845/2017-8).

\section{References}

1. Parrini, R.; Pardo, C. S.; Pacheco, J. F.; Conhecendo as plantas cujos frutos e recursos florais são consumidos pelas aves na Mata Atlântica do Parque Nacional da Serra dos Órgãos. Atualidades Ornitologicas 2017, 199, 38. [Link]

2. Martins, A. P.; Salgueiro, L.; Vila, R., Tomi, F.; Canigueral, S.; Casanova, J.; Adzet, T.; Essential oils from four Piper species. Phytochemistry 1998, 49, 2019. [PubMed]

3. Bezerra, D. P.; Militão, G. C.; de Castro F. O.; Pessoa, C.; de Moraes, M. O.; Silveira, E. R.; Piplartine induces inhibition of leukemia cell proliferation triggering both apoptosis and necrosis pathways. Toxicology in Vitro 2007, 21, 1. [PubMed]

4. Oliveira, C. S.; Barros, R. F. M.; Moita Neto, J. M.; Medicinal plants used in rural communities from Oeiras Municipality, in the semi-arid region of Piauí state (PI), Revista Brasileira de Plantas Medicinais 2010, 12, 282. [PubMed]

5. Gogosz, A. M.; Boeger, M. R. T.; Negrelle, R. R. B.; Bergo, C.; Anatomia foliar comparativa de nove espécies do gênero Piper (Piperaceae) Rodriguésia 2014, 63, 405. [RefCross]

6. dos Santos, V. L. P.; Rodrigues, I. C. G.; Berté, R.; Raman, V., Messias-Reason, I. J.; Budel, J. M.; Review of Piper species growing in the Brazilian State of Paraná with emphasize on the vegetative anatomy and biological activities. The Botanical Review 2021, 1, 32. [CrossRef]

7. Scodro, R. B. L.; Pires, C. T. A; Carrara, V. S.; Lemos, C. O T.; Cardozo-Filho, L.; Souza, V. A.; Corrêa, A. G.; Siqueira, V. L. D.; Lonardoni, M. V. C.; Cardoso, R. F.; Neolignans antituberculose de Piper regnelli. Phytomedicine 2013, 20, 600. [CrossRef] [PubMed] 
8. Bernuci, K. Z., Iwanaga, C. C., Fernandez-Andrade, C. M. M., Lorenzetti, F. B., Torres-Santos, E. C., Faiões, V. D. S.;Cortez, D. A. G. Evaluation of chemical composition and antileishmanial and antituberculosis activities of essential oils of Piper species. Molecules 2016, 21, 1698. [CrossRef] [PubMed]

9. Dosoky, N. S.; Satyal, P.; Barata, L. M.; Da Silva, J. K. R.; Volatiles of Black Pepper Fruits (Piper nigrum L.). Molecules 2019, 24, 4244. [CrossRef] [PubMed]

10. Guimarães, E. F.; Mautone, L.; Magalhães, H. G.; Guimarães, L. A.; Estudos taxonômico e farmacoquímico e bioensaios de Piper lhotzkyanum Kunth (Piperaceae), uma espécie ocorrente em Minas Gerais. Daphne 1992, 2, 10. [Link]

11. Queiroz, G. A.; Guimarães, E. F.; Sakuragui, C. M. S.; First record of Piper robustipedunculum Yunck. (Piperaceae) in the state of Pernambuco, Brazil. Check List 2020, 16, 1149. [Link]

12. Flora do Brasil 2020 em construção. Jardim Botânico do Rio de Janeiro. Disponible em: < http://floradobrasil.jbrj.gov.br/ >. Acesso em: 13 outubro 2020.

13. Moreira, D. L.; Guimarães, E. F.; Kaplan, M. A. C.; Non-polar constituents from Piper lhotzkyanum. Phytochemistry 1998, 49, 1339. [CrossRef]

14. Moreira, D.; Guimarães, E. F.; Kaplan, M. A. C.; C-glucosyl flavone from Leaves of Piper lhotzkyanum. Phytochemistry 2000, 55, 783. [CrossRef]

15. Abbas, H. S.; Abou Baker, D. H.; Recent challenges in tuberculosis treatments: a review. Plant Archives 2020, 20, 3539.

16. Sieniawska, S. R.; Swatko-Ossor, M.; Napiorkowska, A.; Przekora, A.; Ginalska, G.; Augustynowicz-Kopec, E.; The Effect of Combining Natural Terpenes and Antituberculous Agents against Reference and Clinical Mycobacterium tuberculosis Strains. Molecules 2018, 23, 176. [CrossRef] [PubMed]

17. Leigh-de Rapper, S.; Sandy, F. V. V.; Odoriferous Therapy: a Review Identifying Essential Oils against Pathogens of the Respiratory Tract. Chemistry \& Biodiversity 2020, 17, e2000062. [CrossRef] [Pubmed]

18. Wang, R. L.; Gao, Y.; Xing X. Analysis of Chemical Composition and Assessment of Antioxidant, Cytotoxic and Synergistic Antibacterial Activities of Essential Oils from Different Plant Parts of Piper boehmeriifolium. Chemistry \& Biodiversity 2020, 17, e2000245. [CrossRef] [PubMed]

19. Sieniawska, E.; Swatko-Ossor, M.; Sawicki, R.; Ginalska, G.; Morphological changes in the overall Mycobacterium tuberculosis H37Ra cell shape and cytoplasm homogeneity due to Mutellina purpurea $\mathrm{L}$. essential oil and its main constituents. Medical Principles and Practice 2015, 24, 527. [CrossRef]

20. Tripathi, R. P.; Tewari, N.; Dwivedi, N.; Tiwari, V. K.; Fighting tuberculosis: An old disease with new challenges. Medicinal Research Review 2005, 25, 93. [CrossRef] [PubMed]

21. Nayyar, A.; Jain, R.; Recent advances in new structural classes of anti-tuberculosis agents. Current Medicinal Chemistry 2005, 12, 1873. [CrossRef] [PubMed]

22. Boren, K.; Crown, A. A.; Carlson R. Multidrug and Pan-Antibiotic Resistance-The Role of Antimicrobial and Synergistic Essential Oils: A Review. Natural Product Communications 2020, 15, 1. [CrossRef]
23. Macedo, R. O. S.; Gonçalves, J. W. C.; de Menezes, O. D. Jr.; Justino, A. C. A.; do Nascimento, M. K. S. L.; Oliveira, R. J. C.; Coutinho, H. D. M.; Photoinduced Antibacterial Activity of the Essential Oils from Eugenia brasiliensis Lam and Piper mosenii C. DC. by Blue Led Light. Antibiotics 2019, 8, 242. [CrossRef] [PubMed]

24. Salehi, B.; Zakaria, Z. A.; Gyawali, R.; Ibrahim, S. A.; Rajkovic, J.; Shinwari, Z. K.; Valussi, M.; Piper species: a comprehensive review on their phytochemistry, biological activities and applications. Molecules 2019, 24, 1364. [CrossRef] [PubMed]

25. Leal, A. L.; Machado, A. J. T.; Bezerra, C. F.; Inácio, C. E. S.; Rocha, J. E.; Sales, D. L.; Ferriani, A. P.; Chemical identification and antimicrobial potential of essential oil of Piper rivinoides Kunth (BETIS-WHITE). Food and Chemical Toxicology 2019, 131, 110559. [CrossRef] [PubMed]

26. Daniel, N. A.; Ahmad, F. B.; Assim, Z.; Pin, C. H.; Chemical constituents, antioxidants and cytotoxicity of essential oils of Piper arborescens and Piper caninum. Malaysian Journal of Fundamental and Applied Sciences 2019, 15, 830. [Link]

27. KrinskI, D.; Foerster, L. A.; Deschamps, C.; Ovicidal effect of the essential oils from 18 Brazilian Piper species: controlling Anticarsia gemmatalis (Lepidoptera, Erebidae) at the initial stage of development. Acta Scientiarum Agronomy 2018, 40, e35273. [CrossRef]

28. Oliveira, G. L.; Moreira, D. L.; Mendes, A. D. R.; Guimarães, E. F.; Figueiredo, L. S.; Kaplan, M. A. C.; Martins, E. R.; Growth study and essential oil analysis of Piper aduncum from two sites of Cerrado biome of Minas Gerais State, Brazil. Revista Brasileira de Farmacognosia 2013, 23, 743. [CrossRef]

29. Ramos, Y. J.; Moreira, D. L. Seasonal Study of Essential Oil from Aerial Parts of Peperomia galioides Kunth (Piperaceae). Revista Virtual de Química 2019, 11, 1540. [CrossRef]

30. Ramos, Y. J.; Brito-Machado, D.; Queiroz, G. A.; Guimarães, E. F.; Defaveri, A. C. A.; Moreira, D. L.; Chemical composition of the essential oils of circadian rhythm and of different vegetative parts from Piper mollicomum Kunth- A medicinal plant from Brazil. Biochemical Systematics and Ecology 2020, 92, 104116. [CrossRef]

31. Wasicky, R.; Uma modificação do aparelho de Clevenger para extração de óleos essenciais. Revista Faculdade de farmácia e Bioquímica 1963 1, 81. [Link]

32. Adams R.; Identification of essential oil components by gas chromatography/mass spectrometry, 4th ed., Allured Publishing Corporation: Carol Stream, 2007.

33. Gomez-Flores R.; Gupta S.; Tamez-Guerra R.; Mehta R. T.; Determination of MIC's for Mycobacterium avium-M. intracellulare complex in liquid medium by a colorimetric method. Journal of Clinical Microbiology 1995, 33, 1842. [CrossRef] [ubMed]

34. Autran, E. S.; Neves, I. A.; da Silva, C. S. B.; Santos, G. K. N.; da Câmara, C. A. G.; Navarro, D. M. A. F.; Chemical composition, oviposition deterrent and larvicidal activities against Aedes aegypti of essential oils from Piper marginatum Jacq.(Piperaceae). Bioresource Technology 2009, 100, 2288. [CrossRef] 
35. Marques, A. M.; Barreto, A. L. S.; Batista, E. M.; Curvelo, J. A.; D. A, R.; Velozo, L. S. M.; Moreira, D. L.; Kaplan, M. A. C.; Chemistry and biological activity of essential oils of Piper Claussenianum (Piperaceae). Natural Product Communications 2010, 5, 1840. [CrossRef]

36. Khan, M. Comparative physicochemical evaluation of fruits and antidepressant potential of volatile oils of fruits of local Piper species. Oriental Journal of Chemistry 2015, 31: 545. [CrossRef]

37. Varughese, T.; Unnikrishnan, P. K.; Deepak, M.; Balachandran, I.; Rema Shree A. B.; Chemical composition of the essential oils from stem, root, fruit and leaf of Piper longum Linn. Journal Essential Oil-Bear Plants 2016, 19, 52. [CrossRef]

38. Valadares, A. C. F.; Alves, C. C. F.; Alves, J. M.; De Deus, I. P.; De Oliveira Filho, J. G.; dos Santos, T. C. L.; Miranda, M. L.; Essential oils from Piper aduncum inflorescences and leaves: chemical composition and antifungal activity against Sclerotinia sclerotiorum. Anais Academia Brasileira de Ciências 2018, 90, 2691. [CrossRef] [PubMed]

39. Ramos, Y. J.; De Brito, D. M.; de Queiroz, G. A.; Guimarães, E. F.; Defaveri, A. C. A.; De Lima, D. M.; Chemical composition of the essential oils of circadian rhythm and of different vegetative parts from Piper mollicomum Kunth-A medicinal plant from Brazil. Biochemical Systematics and Ecology 2020, 92, 104116. [CrossRef]

40. Neghliz-Benabdelkader, H.; Benabdelkader, T.; Halladj, F.; Jullien, F.; Characterization of The Chemical Diversity in Essential Oils from Vegetative and Reproductive Organs of Ammodaucus leucotrichus subsp. leucotrichus Coss. \& Dur. Growing in Algeria. Journal of Essential Oil Bearing Plants 2021, 1, 11. [CrossRef]

41. Işcan, G.; Kirimer, N.; Demirci, F.; Demirci, B.; Noma, Y.; Başer, K. H. C.; Biotransformation of (-) - $(R)-\alpha$-phellandrene: Antimicrobial Activity of Its Main Metabolite. Chemistry \& Biodiversity 2012, 9, 1525. [PubMed]

42. Lin, J. J.; Lin, J. H.; Hsu, S. C.; Weng, S. W.; Huang, Y. P.; Tang, N. Y.; Chung, J. G.; Alpha-phellandrene promotes immune responses in normal mice through enhancing macrophage phagocytosis and natural killer cell activities. in vivo 2013, 27, 809. [PubMed]
43. Vendruscolo, A.; Takaki, I.; Bersani-Amado, L. E.; Dantas, J. A.; Bersani-Amado, C. A.; Cuman Antiinflammatory and antinociceptive activities of zingiberofficinale roscoe essential oil in experimental animal models. Indian Journal of Pharmacology 2006, 38, 58. [CrossRef]

44. Erazo, S.; Delporte, C.; Negrete, R.; Garcia, R.; Zaldivar, M.; Iturra, G.; Caballero, E.; Lopez, J. L.; Backhouse, N.; Constituents and biological activities of Schinuspolygamus. Journal of Ethnopharmacology 2006, 107, 395. [CrossRef]

45. Lin, J. J.; Lu, K. W.; Ma, Y. S.; Tang, N. Y.; Wu, P. P.; Wu, C. C.; Chung, J. G.; Alpha-phellandrene, a natural active monoterpene, influences a murine WEHI-3 leukemia model in vivo by enhancing macrophague phagocytosis and natural killer cell activity. In Vivo 2014, 28, 583. [Link]

46. Piccinelli, A. C.; Santos, J. A.; Konkiewitz, E. C.; Oesterreich, S. A.; Formagio, A. S. N.; Croda, J.; Kassuya, C. A. L.; Antihyperalgesic and antidepressive actions of $(R)-(+)$-limonene, $\alpha$-phellandrene, and essential oil from Schinus terebinthifolius fruits in a neuropathic pain model. Nutritional Neuroscience 2015, 18, 217. [CrossRef] [PubMed]

47. Bueno-Sánchez, J. G; Martínez-Morales, J. R.; Stashenko, E. E.; Ribón, W.; Anti-tubercular activity of eleven aromatic and medicinal plants occurring in Colombia. Biomédica 2009, 29, 51. [CrossRef] [PubMed]

48. Hancock, R. E. W.; The bacterial outer membrane as a drug barrier. Trends in Microbiology 1997, 5, 37. [CrossRef]

49. Cowan, M. M.; Plant products as antimicrobial agents. Clinical Microbiology Reviews 1999, 12, 564. [CrossRef] [PubMed]

50. Trombetta, D.; Castelli, F.; Sarpietro, M. G.; Venuti, V.; Cristani, M.; Daniele, C.; Saija, A.; Mazzanti G.; Bisignano, G.; Mechanisms of Antibacterial Action of Three Monoterpenes. Antimicrobial Agents and Chemotherapy 2005, 49, 2474. [CrossRef] [PubMed]

51. Andrade-Ochoa; S.; Nevárez-Moorillón, G. V.; Sánchez-Torres, L. E.; Villanueva-garcía, M; Sánchez-Ramírez, B. E.; RodríguezValdez, L. M; Rivera-Chavira, B. E.; Quantitative structureactivity relationship of molecules constituent of different essential oils with antimycobacterial activity against Mycobacterium tuberculosis and Mycobacterium bovis. BMC Complementary and Alternative Medicine 2015, 15, 1. [CrossRef] [PubMed] 